\title{
Physical and chemical attributes of prickly pear cactus (Opuntia ficus-indica) varieties Copena, Pelon Blanco and Pelon Rojo
}

\author{
Rössel-Kipping, Erich Dietmar ${ }^{1^{*}}$, Ortiz-Laurel, Hipolito ${ }^{2}$, Moreno-Ovalle, Flor Margarita"; $^{1}$ \\ López-Martínez, Laura Araceli ${ }^{3}$; Amante-Orozco, Alejandro ${ }^{1}$

\begin{abstract}
${ }^{1}$ Colegio de Postgraduados, Campus San Luis Potosí. Iturbide 73, Salinas de Hgo., S.L.P., México. ${ }^{2}$ Colegio de Postgraduados, Campus Córdoba. Manuel León, Amatlán de los Reyes, Veracruz, México. ${ }^{3}$ Universidad Autónoma de San Luis Potosí, Coordinación Académica Región Altiplano Oeste. Salinas de Hidalgo, S.L.P., México.
\end{abstract}

*Corresponding author: edietmar@colpos.mx

\section{ABSTRACT}

Objective: attest and compare the fundamental attributes for fresh raw cactus cladodes and its chemical constituent's quality when dried and grounded for three varieties of prickly pear cactus "Copena", "Pelon blanco" and "Pelon rojo".

Design/methodology/approach: measurements of the physical attributes and chemical constituents were made by using proved and reliable techniques. Data will aid to explore the potential for these cactus materials when being handled from basic to complex processes, considering its need for size and quality of storage and their effect when they interact with processing devices and handling apparatus for the new product being elaborated.

Results: the physical attributes among the three assessed cactus varieties showed slight differences in their parameters but length, wide and electric conductivity. While for their chemical analysis, cactus cladodes were chopped, dried and grounded. Chemical compounds showed slight differences between the three varieties, but Pelon blanco had a higher fat percentage and the lowest zinc and potassium concentration. None of the varieties had iron.

Limitations on study/implications: there was no management on the prickly pear cactus production. The assessment of the cultivars' attributes was as they were from the field. Stabilization of the chemical constituents of Pelon blanco could be necessary, according to the expected features of new products, or lead to a new line of by-products.

Findings/conclusions: mechanical handling of raw cladodes around the premises is facilitated, and its uses and maintenance are fewer management costs. Flour from each variety was kept at around $10 \%$ water content to safeguarding storage. Regard the protein and carbohydrates content, flour of the three varieties ensure integration with other compounds and guarantees new products with high protein content

Keywords: agri-food, byproducts, physical-chemical, measurement techniques, prickly cactus. 


\section{INTRODUCTION}

$T \bigcap \cap \bigcirc \bigcirc\left[\begin{array}{l}\text { (Opuntia ficus-indica) } \\ \text { is cacti of agronomical }\end{array}\right.$ importance, both for its fruits and stems, used as forage or consumed as a vegetable (Kiesling, 1995). The "nopal" is scattered throughout various regions of the world (Figure 1). Of the 258 recognized species, 101 are found in Mexico (Luna Vázquez, 2011); out of these, there are 76 wild ones (sensu stricto), from which approximately half distribute in the central-north region or southern highlands of Mexico (Reyes-Agüero et al., 2005).

According to Vásquez-Alvarado et al. (2008), at the highland area of Zacatecas-San Luís Potosí, Mexico, the main cultivated species are: O. leucotricha (duraznillo nopal), O. streptacantha (cardón nopal), O. robusta (tapón nopal), O. cantabrigiensis (cuijo nopal), O. rastrera (creeping nopal), $O$. lindheimeri (cacanapo nopal), and O. leptocaulis (tasajillo nopal). SIAP (2009) documents that the state of San Luis Potosi (SLP) ranks sixth at the Mexican level, with a production extension of 388 ha of vegetable nopal (medium growth cladodes). In the case for prickly pear fruits ("tunas"), the state of San Luis Potosi has 416 ha of cultivated nopal, which means that SLP produces a greater quantity of nopales for prickly pear production.

From the nopal juices can be extracted, as well as nopal powder with a high fiber content which mixed with other flours can be used for cookies, cereals or tortillas. It can also be an ingredient to produce soaps, hand sanitizer and shampoo, yogurt, jam, syrups, bread, nopal flour, weight-loss capsules, reductive gel, moisturizing cream, pickled nopal and toothpaste (Sáenz-Carmen, 2006). industrial processes in the links of the chain value are pointed out, due the fact of the standardizing use of technologies in agricultural holdings, with which the development of the crop is algorithmically modelled to plan its future commercialization. Hence, to integrate the cactus into the agroindustrial processes, a greater knowledge of its attributes is required.

Today the world population is around 8000 million, who demand a healthy and sustainably produced diet (Siess Wolfgang, 2020). Therefore, it is convenient to generate food alternatives to provide the constantly growing population, which provide favourable physiological properties for health and reduce diseases risk, taking advantage of the existing biomass. It is important to know the physical and chemical characteristics of the nopal (Opuntia ficus-indica) cultivars "Copena", "Pelón blanco" and "Pelón rojo", which comprise the largest crop surface area recorded at the Potosi highlands. These results will orient its destination towards the agroindustry, seen as a tool for standardization and automation of processes, which facilitate their efficient handling and processing, also facilitating obtaining raw materials for the elaboration of high nutritional value products.

\section{MATERIALS AND METHODS}

In this study, fresh two years old cladodes from three Opuntia ficus-indica cultivars were assessed: Copena, Pelón blanco and Pelón rojo. These were collected during the fall season (September-December). They were dried in a DZF-6090 model oven, for 10 hours at $60{ }^{\circ} \mathrm{C}$ to dehydrate the samples. Later, a milling process was carried out to obtain flour, using a Krups
Agribusiness is a cluster of processes in which raw materials whose origin is agricultural, livestock or forestry production are conditioned, preserved or transformed (Ibarra-Alejo, 1986). Agribusiness can be divided into food (transforming raw materials into food with different formats and properties) and non-food (raw materials used for different processes not linked to food). Due to the development of technology and its advances in agriculture, it is called Agroindustry, Agro 4.0 or Smart Agro, where the importance of agro-intelligent

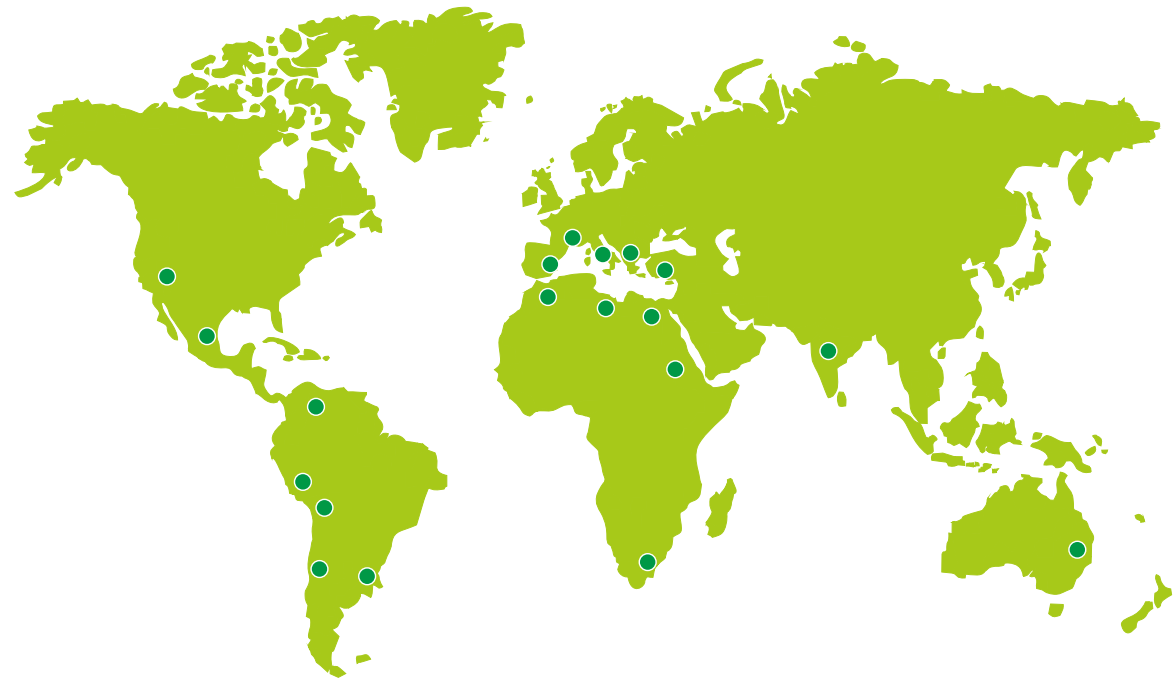

Figure 1. Worldwide geographic distribution of the nopal (FAO, 2006). 
GX 410011 model mill ending in a $0.00381 \mathrm{~mm}$ mesh screen (Figure 2).

The values and possible differences exhibited by the physical and chemical attributes between the nopal (Opuntia ficus-indica) cultivars, were processed through an analysis of variance (ANOVA) and subsequently by means of contrasts for each parameter, using the STATISTICA software. V.12 (StatSoft, Inc., Tulsa, OK, USA) confronting in all cases to a significance level of $p=0.05$.

The physical dimensions of the cladodes were determined ( $n=5$ measurements) using a ruler (length and width) and a vernier (thickness) with digital caliper (0.001 $\mathrm{mm}$ precision). In the length measured from the apex base, the equatorial width was determined in the widest central zone of the cladode and the thickness was measured on the profile of the cladode.

The conductivity depends on the atomic and molecular structure of the material. The unit of electrical conductivity is Siemens (S) which gives the definition of $1 \mathrm{~S}$ is the electrical conductivity of a conductor of resistance $1 \Omega$. According to Crespo Villalaz (2004) $1 \mathrm{~S} * \mathrm{~m}^{-1}$ is the electrical conductivity in a homogeneous conductor with a $1 \mathrm{~m}^{2}$ cross section and a $1 \mathrm{~m}$ length, whose conductance is $1 \mathrm{~S}$. The electrical conductivity of the prickly pear cladodes of the Copena, Pelón blanco and Pelón rojo cultivars were assessed with a Kinzo model 18d265 CE multimeter at five different points of the cladode with two repetitions at the same points in each cladode of each variety, in the lower part of cladode, in the center and lateral ends of the cladode and in their upper part. The values obtained by the multimeter in $k \Omega$ were converted to $\mathrm{ms}$, following equations: first conversion to $m S: m S=\frac{1}{k \Omega}$

second conversion $\mathrm{mS}$ to $\mathrm{mS} / \mathrm{m}$

considering the distance coefficient between electrodes, which was $5 \mathrm{~cm}$.

Conversion to $m s / m: \frac{m S}{m}=m s * 20$

Where: $m S=$ millisiemens and $k \Omega=$ kilo $O h m$.

The determination of internal friction and internal friction angle were determined for the flours of the three nopal cultivars. The internal friction and the internal friction angle were determined using the formula:

$$
\tan \phi=\mu_{i}=\frac{h}{r}
$$

Where: $h$ corresponds to the height of the inverted cone formed by the flour and $r$ to the corresponding radius.

To determine the density of the cladodes, $10 \mathrm{~L}$ of water were placed in a square polyethylene container measuring $83 \mathrm{~cm} \times 50 \mathrm{~cm} \times 35.4 \mathrm{~cm}$ (length, width and height), subsequently the water level in the container was noted and each cladode was introduced into the container. The reached height with the cladode was again marked, five repetitions per cultivar. The densities were determined using the equation:

$$
\rho=\frac{m}{v}
$$

Where: $m$ corresponds to the weight in $\mathrm{kg}$ of the nopal cladode and $v$ corresponds to the displaced amount of water in $\mathrm{m}^{3}$

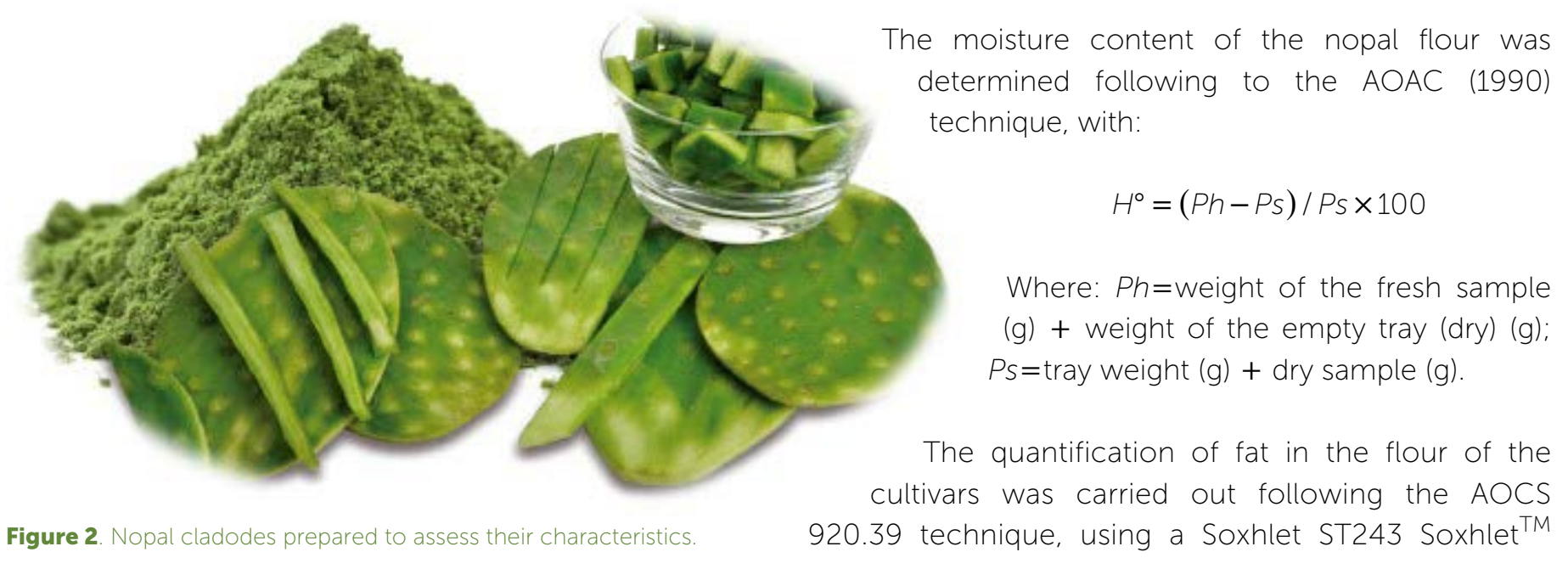


Extraction unit. Three repetitions were done, using the formula:

$$
\% \text { Grasa }=\frac{V a a b-V a b}{h} * 100
$$

Where: $V a a b=$ Weight in $g$ of the aluminum beaker + oil + three borosilicate beads (b). Vab=Aluminum cup (Va) + three borosilicate beads (b) $h=$ flour.

The determination of proteins in the flours was carried out taking as reference the Standard NMX-F-068-S (1980). Which determine of the total nitrogen of the sample by sulfuric acid digestion. The total nitrogen (\%) present in the sample was calculated using the equation:

$$
N \%=(V * N * 0.014 * 100) / m
$$

Where: N\% corresponds to the nitrogen percentage (\%), $V$ to the hydrochloric acid volume of used in the titration $(\mathrm{ml}), N$ the normality of hydrochloric acid, $m$ the mass of the sample (g), 0.014=nitrogen milliequivalent.

The proteins percentage (\%) was obtained by multiplying the $(\%)$ of nitrogen obtained by the corresponding factor.

The carbohydrate content determination was carried out following the standard NMX-F-066-S (1978). The determination of direct and total reducers in the feed with the equation:

$$
A(\%)=25000 * T V * P
$$

The phosphorus in de cladodes determination was carried out based on the phosphorus method by spectrophotometry, which is a quantitative titration colorimetric method. The method is based on the formation of a hetero polyacid with a vanadate-molybdate reagent (yellow in color and soluble in water) that absorbs light at $430 \mathrm{~nm}$, the equipment used was a visible range spectrophotometer, model Genesys 105 vis. The determination of $\mathrm{Zn}$, Fe, $K$ was carried out by atomic absorption spectrophotometry, using the Aurora Instruments-1200 equipment.

\section{RESULTS AND DISCUSSION}

The results of the sizes of the prickly pear cladodes in the three cultivars (Copena, Pelón blanco and Pelón rojo) is shown in Table 1 . Where the five determinations for each of the parameters described

are included, as well as their mean and respective standard deviation.

The Copena and Pelón blanco cultivars do not show a significant difference ( $p>0.05)$, the Pelón rojo cultivar is the one with the smallest cladodes $(p<0.05)$. Regarding width, the cv. Copena with $26.20 \mathrm{~cm}$ is significantly bigger compared to the Pelón blanco with $22.60 \mathrm{~cm}$ and Pelón rojo vcultivars with $21.10 \mathrm{~cm}(p<0.05)$. Regard thickness, there is no significant difference $(p<0.05)$ regardless of the variety. The foregoing presupposes the ease and feasibility of the technical and technological application, since the length, width and thickness dimensions of the evaluated varieties meet the characteristic parameters of the nopales from the Opuntia ficus-indica genus, measured in 38 crops aged between 2 and 3 years (Reyes-Agüero et al., 2005)

The electrical conductivity directly depends on the atomic structure of the material, as well as on the temperature at which it is found or the state in which it is (liquid, solid, gaseous) and is representative of the thermal, optical, acoustic conductivity, etc., hence its importance to define technological processes. The obtained results in the Opuntia cladodes are shown in Table 2, where it is observed that the electrical conductivity of the cv. Pelón rojo with a value of 3.27 was significantly lower

Table 1. Size of the Opuntia ficus-indica prickly pear cladodes.

\begin{tabular}{l|l|l|l} 
Variety & Length $(\mathrm{cm})$ & Width $(\mathrm{cm})$ & Thickness $(\mathrm{cm})$
\end{tabular}

\begin{tabular}{l|l|l|l} 
Copena & 45.00 & 26.00 & 3.60 \\
\hline Copena & 48.00 & 33.00 & 4.20 \\
\hline Copena & 47.50 & 20.50 & 1.80 \\
\hline Copena & 46.00 & 24.50 & 2.00 \\
\hline Copena & 42.00 & 27.00 & 1.90 \\
\hline Average & $45.70(2.39)^{\mathrm{a}}$ & $26.20(2.54)^{\mathrm{a}}$ & $2.70(1.12)^{\mathrm{a}}$ \\
\hline Pelón Blanco & 44.00 & 23.00 & 2.50 \\
\hline Pelón Blanco & 34.00 & 19.00 & 2.00 \\
\hline Pelón Blanco & 43.00 & 26.00 & 2.40 \\
\hline Pelón Blanco & 42.00 & 24.00 & 1.70 \\
\hline Average & $42.20(5.12)^{\mathrm{a}}$ & $22.602 .70)^{\mathrm{b}}$ & $2.26(0.40)^{\mathrm{a}}$ \\
\hline Pelón Rojo & 36.50 & 19.00 & 2.00 \\
\hline Pelón Rojo & 32.00 & 19.50 & 1.50 \\
\hline Pelón Rojo & 34.50 & 20.00 & 2.00 \\
\hline Pelón Rojo & 45.00 & 25.00 & 2.20 \\
\hline Pelón Rojo & 39.00 & 22.00 & 2.00 \\
\hline Average & $37.40(4.97)^{\mathrm{b}}$ & $21.10(2.46)^{\mathrm{b}}$ & $1.94(0.26)^{\mathrm{a}}$ \\
\hline
\end{tabular}

a $\&$ b for the same analyzed parameter, a different superscript shows a significant difference between varieties. $(p<0.05)$. 


\begin{tabular}{|c|c|c|c|c|c|c|c|c|c|c|c|}
\hline V & $\mathrm{k} \Omega$ & $\mathrm{mS}$ & $\mathrm{mS} / \mathrm{m}$ & V & $\mathrm{k} \Omega$ & $\mathrm{mS}$ & $\mathrm{mS} / \mathrm{m}$ & V & $\mathrm{k} \Omega$ & $\mathrm{mS}$ & $\mathrm{mS} / \mathrm{m}$ \\
\hline 1 & 5.00 & 0.20 & 4.00 & 2 & 5.00 & 0.20 & 4.00 & 3 & 7.00 & 0.14 & 2.86 \\
\hline 1 & 5.00 & 0.20 & 4.00 & 2 & 4.00 & 0.25 & 5.00 & 3 & 8.00 & 0.13 & 2.50 \\
\hline 1 & 5.00 & 0.20 & 4.00 & 2 & 4.00 & 0.25 & 5.00 & 3 & 6.00 & 0.17 & 3.33 \\
\hline 1 & 5.00 & 0.20 & 4.00 & 2 & 4.00 & 0.25 & 5.00 & 3 & 6.00 & 0.17 & 3.33 \\
\hline 1 & 5.00 & 0.20 & 4.00 & 2 & 5.00 & 0.20 & 4.00 & 3 & 6.00 & 0.17 & 3.33 \\
\hline 1 & 5.00 & 0.20 & 4.00 & 2 & 4.00 & 0.25 & 5.00 & 3 & 6.00 & 0.17 & 3.33 \\
\hline 1 & 6.00 & 0.19 & 3.33 & 2 & 4.00 & 0.25 & 5.00 & 3 & 6.00 & 0.17 & 3.33 \\
\hline 1 & 3.50 & 0.29 & 5.71 & 2 & 4.00 & 0.25 & 5.00 & 3 & 5.00 & 0.20 & 4.00 \\
\hline 1 & 5.00 & 0.20 & 4.00 & 2 & 4.00 & 0.25 & 5.00 & 3 & 6.00 & 0.17 & 3.33 \\
\hline 1 & 3.50 & 0.29 & 5.71 & 2 & 5.00 & 0.20 & 4.00 & 3 & 6.00 & 0.17 & 3.33 \\
\hline$\sum$ & 4.80 & 0.22 & $4.28^{a}$ & & 4.30 & 0.24 & $4.70^{a}$ & & 6.20 & 0.17 & $3.27^{b}$ \\
\hline$\Delta$ & $(0.75)$ & $(0.04)$ & $(0.78)$ & & $(0.48)$ & $(0.02)$ & $(0.48)$ & & (0.79) & $(0.02)$ & $(0.38)$ \\
\hline
\end{tabular}

$V=$ cactus prickly variety, $1=$ Copena; $2=$ Pelon Blanco, $3=$ Pelon rojo, $\sum=$ average, $\Delta=$ deviation; a \& b for the same analyzed parameter, a different superscript shows a significant difference between varieties. $(p<0.05)$.

compared to the Copena and Pelón Blanco cultivars, which reported values of 4.28 and 4.70 respectively $(p<0.05)$.

Table 3 shows the results obtained from the internal friction $\mu_{i} /-1$.

The angle of internal friction which corresponds to the angle whose tangent is the relation between the sliding resists force, along a plane, and the normal force applied to said plane and depends on the forces that intervene in the flow of the powder, such as gravity, friction, cohesion (Crespo Villalaz, 2004). With values of 15.65 , 16.24 and 14.79 for the Copena, Pelón blanco and Pelón rojo varieties respectively, they show no significant differences ( $p>0.05)$.

The above indicates that they are free-flowing powders. When the attraction forces between the particles, that is to say, cohesion is high, there are problems with the flow of the powders, which can present flow problems in the silos. Hence, technological applications represent reduction in processing costs, since approximately one third of energy resources are lost due to friction, in addition to extending the useful life of the machinery.

Density is an inherent characteristic for both solids and liquids and is related to buoyancy. Table 4 shows the results obtained for the humidity determinations of the cladodes of Opuntia ficus-indica. The results of 0.82 , 0.81 and $0.92 \mathrm{~g} \mathrm{~cm}^{3-1}$ for the Copena, Pelón blanco and Pelón rojo cultivars respectively, which show that there is no significant difference between their densities $(p>0.05)$.

The moisture content determination, particularly for dehydrated or dry foods, is of utmost importance, since if the moisture content is high, the shelf life of the flour will decrease significantly, due to the proliferation of fungi and bacteria, as well as chemical reactions. (i.e., enzymatic reactions) and physical such as fluidity change, condensation, corrosion, adhesion, etc.

\begin{tabular}{|c|c|c|c|}
\hline Characteristic & Copena & Pelón blanco & Pelón rojo \\
\hline Height (cm) & $1.29(0.15)$ & $1.34(0.16)$ & $1.24(0.19)$ \\
\hline Wide $(\mathrm{cm})$ & $9.18(0.19)$ & $9.25(0.45)$ & $9.37(0.36)$ \\
\hline Radious (cm) & $4.59(0.10)$ & $4.62(0.22)$ & $4.68(0.18)$ \\
\hline Internal friction $\mu_{i}$ & $0.28(0.28)^{a}$ & $0.29(0.04)^{a}$ & $0.26(0.04)^{a}$ \\
\hline Angle of internal friction /tan/ & $15.65(1.94)^{b}$ & $16.24(2.31)^{b}$ & $14.79(2.40)^{b}$ \\
\hline
\end{tabular}

**all average values are displayed $n=100$ repetitions; a $\& b$ for the same analyzed parameter, an equal superscript shows that there is not a significant difference between varieties. $(p>0.05)$.
Therefore, it is recommended that the maximum humidity percentage in dehydrated products is not greater than 10\% for long-term storage. The obtained moisture percentages in Opuntia ficusindica flours are shown in Table 5. The $\mathrm{cv}$. Pelón rojo had the lowest moisture content with a value of $5.01 \%$; However, the difference is not significant compared 


\begin{tabular}{c|c|c|c|c|c}
\multicolumn{3}{c}{ Table 4. Density of cactus prickly cladodes for varieties Copena, Pelon blanco and Pelon rojo. } \\
Variety & $\begin{array}{c}\text { Density } \\
\left(\mathrm{g} \mathrm{cm}^{3-1}\right)\end{array}$ & Variety & $\begin{array}{c}\text { Density } \\
\left(\mathrm{g} \mathrm{cm}^{3-1}\right)\end{array}$ & Variety & $\begin{array}{c}\text { Density } \\
\left(\mathrm{g} \mathrm{cm}^{3-1}\right)\end{array}$ \\
\hline Copena & 0.92 & Pelón blanco & 1.08 & Pelón rojo & 1.11 \\
\hline Copena & 0.66 & Pelón blanco & 0.64 & Pelón rojo & 0.49 \\
\hline Copena & 0.90 & Pelón blanco & 0.33 & Pelón rojo & 0.85 \\
\hline Copena & 0.81 & Pelón blanco & 0.92 & Pelón rojo & 0.96 \\
\hline Copena & 0.83 & Pelón blanco & 1.08 & Pelón rojo & 1.17 \\
\hline Average & $0.82^{\mathrm{a}}(0.10)$ & & $0.81^{\mathrm{a}}(0.32)$ & & $0.92^{\mathrm{a}}(0.27)$ \\
\hline
\end{tabular}

a for the same analyzed parameter, an equal superscript shows that there is not a significant difference between varieties. ( $p>0.05)$.

to the Copena and Pelón blanco cultivars with values of $6.26 \%$ and $6.11 \%(p>0.05)$ respectively.

The results of the fat determinations are shown in Table 6 , in which it is observed that the cv. Pelón blanco with $4.5 \%$ fat was significantly higher than the Copena with $2.45 \%$ and Pelón rojo cultivars with $2.90 \%(p<0.05$ ).

The obtained results for crude protein or total protein are shown in Table 7, where it is to be noted that there is no significant difference between the protein determined percentages for the three cultivars $(p>0.05)$.

From the carbohydrates percentages (Table 8) it is observed that, regardless of the assessed variety, there are no differences ( $p>0.05$ ); $15.79 \%$ for the $c v$. Copena,

\begin{tabular}{r|c|c|c|c|c}
\multicolumn{5}{c}{ Table 5. Moisture content (\%) of cactus prickly flour (Copena, Pelon blanco \& Pelon rojo). } \\
Variety & $\begin{array}{c}\text { Moisture } \\
\text { content (\%) }\end{array}$ & Variety & $\begin{array}{c}\text { Moisture } \\
\text { content (\%) }\end{array}$ & Variety & $\begin{array}{c}\text { Moisture } \\
\text { content (\%) }\end{array}$ \\
\hline Copena & 5.55 & Pelón Blanco & 5.91 & Pelón Rojo & 5.42 \\
\hline Copena & 5.37 & Pelón Blanco & 6.7 & Pelón Rojo & 4.35 \\
\hline Copena & 7.85 & Pelón Blanco & 5.73 & Pelón Rojo & 5.25 \\
\hline Deverage & $6.26^{\text {a }}$ & & $6.11^{\text {a }}$ & & $5.01^{\text {a }}$ \\
\hline
\end{tabular}

a for the same analyzed parameter, an equal superscript shows that there is not a significant difference between varieties. ( $p>0.05)$.

Table 6. Percentage of fat from cactus prickly flour.
\begin{tabular}{c|c|c|c|c|c} 
Flour & Extract (\%) & Flour & Extract (\%) & Flour & Extract $(\%)$ \\
\hline Copena & 4.14 & Pelón Blanco & 4.54 & Pelón Rojo & 4.04 \\
\hline Copena & 1.44 & Pelón Blanco & 4.48 & Pelón Rojo & 2.12 \\
\hline Copena & 1.76 & Pelón Blanco & 4.47 & Pelón Rojo & 2.53 \\
\hline Average & 2.45 & & 4.50 & & 2.90 \\
\hline Deviation & $(1.47) \mathrm{a}$ & & $(0.00) \mathrm{b}$ & & $(1.02) \mathrm{a}$ \\
\hline
\end{tabular}

${ }^{a} \&^{b}$ for the same analyzed parameter, a different superscript shows a significant difference between varieties. $(p<0.05)$.
$15.69 \%$ for the cv. Pelón blanco and $14.57 \%$ for cv. Pelón rojo. These results are similar to those reported by Castillo et al. (2013), for Opuntia ficus-indica nopal flour cv. Millar, it also indicates that this variety does not have an effect on the amount of proteins present in nopal flour.

Regard the phosphorus results, also contained in Table 7 , it can be seen that the $\mathrm{cv}$. Copena contains $0.030 \%$ (300 $\mathrm{mg} \mathrm{kg}^{-1}$ ) of phosphorus, which is significantly higher than that presented by the Pelón blanco with $0.010 \%\left(100 \mathrm{mg} \mathrm{kg}^{-1}\right)$ and $\mathrm{cv}$. Pelon rojo with $0.013 \%\left(130 \mathrm{ppm} \mathrm{mg} \mathrm{kg}{ }^{-1}\right.$ ). With regards the results of the zinc determination, shown in Table 11, it is observed that the $\mathrm{cv}$. Copena exhibited a value of $4 \mathrm{mg} \mathrm{L}^{-1}$ and the Pelón rojo variety $3.8 \mathrm{mg} \mathrm{L}^{-1}$, both results are higher than those obtained for the Pelón blanco variety with a value of $0.005 \mathrm{mg} \mathrm{L}^{-1}(p<0.05)$. Iron was not registered in the samples.

Zinc is a vital mineral in the diet relates to cell division and growth, healing, carbohydrate metabolism, as well as growth, neurological development, and the immune system (Grandy et al., 2010). Potassium is a mineral that your body needs to properly function. The results obtained for this element are also concentrated in Table 8 , where it is observed that the $\mathrm{cv}$. Copena with $14000 \mathrm{mg} / \mathrm{l}$ or ppm and the Pelón rojo variety with 11533.33 $\mathrm{mg} \mathrm{L}^{-1}$ are significantly higher than the Pelón blanco variety which contains $4933.33 \mathrm{mg} \mathrm{L}^{-1}(\mathrm{p}<0.05)$.

Finally, it is clearly observed in Table 8 that the nopal is a product lacking iron at least for the analyzed varieties. Although, it is noted that it was not possible to find reports of the iron content in nopal.

The physical attributes, the $\mathrm{cv}$. Pelón rojo was the one with the smallest cladode size, the cr. Copena the largest width and in terms of thickness, no significant differences between the three were 


\begin{tabular}{|c|c|c|c|}
\hline Variety & $\begin{array}{c}\text { Protein } \\
(\%)\end{array}$ & $\begin{array}{c}\text { Carbohydrate } \\
(\%)\end{array}$ & $\begin{array}{c}\text { Phosphorous } \\
(\%)\end{array}$ \\
\hline Copena & 5.65 & 16.09 & 0.03 \\
\hline Copena & 5.96 & 15.49 & 0.03 \\
\hline Copena & & & 0.03 \\
\hline Average & 5.81 & 15.79 & 0.03 \\
\hline Deviation & $(0.22)^{a}$ & $(0.42)^{a}$ & $(0.00)^{a}$ \\
\hline Pelón Blanco & 6.42 & 16.15 & 0.01 \\
\hline Pelón Blanco & 6.37 & 15.22 & 0.01 \\
\hline Pelón Blanco & & & 0.01 \\
\hline Average & 6.40 & 15.69 & 0.01 \\
\hline Deviation & $(0.04)^{a}$ & $(0.66)^{a}$ & $(0.00)^{b}$ \\
\hline Pelón Rojo & 6.20 & 14.4 & 0.01 \\
\hline Pelón Rojo & 6.70 & 14.73 & 0.01 \\
\hline Pelón Rojo & & & 0.02 \\
\hline Average & 6.45 & 14.57 & 0.013 \\
\hline Deviation & $(0.35)^{a}$ & (0.23)a & $(0.006)^{b}$ \\
\hline
\end{tabular}

observed. Regard electrical conductivity, the cladodes of the cv. Pelón rojo showed the lowest values, suggesting a lower concentration of electrically conductive salts. Also, internal friction and internal friction angle did not show significant differences. This parameter is important in agro-industrial processes since high frictions represent high energy costs and equipment wear out. Likewise, the high angles predict handling problems of the flour inside the hoppers or during its dosage, therefore, the results obtained indicate that there will be no wear effects on the machinery used in its handling, transport or transfer. Finally, regarding density, there are no significant differences and in any cases the densities obtained were low and very close to that of water, so the cladodes will float, facilitating their handling.

The determined moisture content for the flours did showed no significant differences, in all cases the moisture content was low (less than 10\%), which guarantees that there will be no microbial development or deterioration of its physical or chemical properties. Regard the fat percentage, this was higher for the cv. Pelón blanco; however, regardless of the variety, the values found were higher than those reported in the literature, which suggests that the geographical location of production or the age of the cladode influence the percentage of present fat. Regard the percentage of protein and

\begin{tabular}{|c|c|c|}
\hline Variety & $\begin{array}{c}\text { Zinc } \\
\left(\mathrm{mg} \mathrm{L}^{-1}\right)\end{array}$ & $\begin{array}{c}\text { Potassium } \\
\left(\mathrm{mg} \mathrm{L}^{-1}\right)\end{array}$ \\
\hline Copena & 4.00 & 13000 \\
\hline Copena & 4.00 & 12800 \\
\hline Copena & 4.00 & 16200 \\
\hline Average & 4.00 & 14000 \\
\hline Deviation & $(0.00) a$ & (1907.888)a \\
\hline Pelón Blanco & 2.00 & 4400 \\
\hline Pelón Blanco & 0.00 & 5000 \\
\hline Pelón Blanco & 0.00 & 5400 \\
\hline Average & 0.005 & 4933.33 \\
\hline Deviation & $(0.006) \mathrm{b}$ & (503.32) b \\
\hline Pelón Rojo & 5.20 & 12400 \\
\hline Pelón Rojo & 2.80 & 10600 \\
\hline Pelón Rojo & 3.40 & 11600 \\
\hline Average & 3.80 & 11533.33 \\
\hline Deviation & (1.25)a & $(901.84)$ a \\
\hline
\end{tabular}

carbohydrates, there are no differences between the cultivars evaluated. These results are favorable since the use of these nopal flours could result in food with a high protein content, compared to other varieties, and is an alternative for the development of specific foods for malnutrition at a lower cost, as it is an abundant raw material. Regard the phosphorus content; the cv. Copena has a higher capacity to develop this compound. While, in the zinc and potassium concentration, the cv. Pelón blanco showed a significantly lower concentration, which suggests that this cultivar has limited capacity for the synthesis of these compounds. Finally, in the three cultivars studied, iron was an absent mineral.

\section{CONCLUSIONS}

In the three varieties of nopal studied, there were no significant differences in internal friction and internal friction angle, in thickness and densities were low and similar to that of water. Although, it was found that; the Red Pelón variety showed the lowest electrical conductivity and the smallest cladode size among those. While the Copena variety was the one with the greatest width. In the flour, The three varieties did not show significant differences in the content of proteins and carbohydrates, as well as in the humidity, with a low value of $10 \%$ and there was no presence of iron. On the other hand, the variety Pelón blanco had the highest percentage of fat 
and the lowest concentration of zinc and potassium, while the variety Copena obtained the highest concentration of phosphorus.

\section{REFERENCES}

Crespo Villalaz, C. (2004). Mecánica de suelos y cimentaciones. Limusa, 5ta ed. México.

Grandy, G., Weisstaub, G., \& López de Romaña, D. (2010). Deficiencia de hierro y zinc en niños. Rev Soc Bol Ped, 49(1): 25-31.

Ibarra Alejo, j. R. (1986). Agroindustria, estado y proceso científico-técnico en la agricultura mexicana. Seminario Internacional de Investigación UACh- Universidad Humboldt.

Kiesling, R. (1995). Origen, domesticación y distribución de Opuntia ficus-indica. J. Profess. Assoc. Cact. Develop, 22(1642): 4747-4748.

Luna Vázquez, J. (2011). Producción intensiva de nopal de verdura. INIFAP. Folleto para productores No. 52. MX-0-310305-32-03-17-10-52. 34p

Reyes-Agüero, J. A., Aguirre-Rivera, J. R., \& Hernández, H. M. (2005). Systematic notes and a detailed description of Opuntia ficus-indica (L.) mill. (Cactaceae). Agrociencia, 39(4) 395-408

Sáenz, Carmen. (2006). Producción industrial de productos no alimentarios. Utilización Agroindustrialdel Nopal, 99-112. BOLETÍN DE SERVICIOS AGRÍCOLAS DE LA FAO, 162

Siess Wolfgang. (2020). Goldene Zwanziger für das 21. Jahrhundert; WILEY-VCH 1-2, 23. Jahrgang, Feburuar 2020, CIT plus, D47412ISSN1436-2597 pp.3

Vázquez-Alvarado, R. E., Valdez-Cepeda, R., Gutiérrez-Ornelas, E., \& Blanco-Macias, F. (1992). Caracterización e Identificación de Nopal Forrajero en el Noreste de México. VI Simposium Taller Producción y Aprovechamiento del Nopal en el Noreste de México, 21-36. 